\title{
A STUDY OF NIGERIA CERTIFICATE IN EDUCATION (NCE) GRADUATES BETWEEN 2003 AND 2015
}

\author{
Dr. Okegbile Akanmu Sunday \\ Federal College of Education (Technical) Bichi \\ School of General Education, PMB 3473, Kano State, Nigeria. \\ Dr. Bashir Sabo Abubakar \\ Federal College of Education (Technical) Bichi \\ Directorate for Degree Programmes, PMB 3473, Kano State, Nigeria
}

\begin{abstract}
This study aimed at assessing NCE graduates from Federal College of Education (Technical) Bichi between 2003 and 2015 with the objective of examining NCE graduates' study experiences, job search, employment and impact of curriculum on work. A descriptive survey which adopted three objectives, tracer study steps posited by Schomburg (2003) was designed using 13 sets of NCE graduates from Federal College of Education (Technical) Bichi with a population of 3,641. The instrument used was tagged NCE Graduates' Tracer Study Core Questionnaire and it is an adapted version of the Standard Instrument for Graduate Tracer Study 2011 of the University XY 2011. The questionnaire was used to obtain data from 590 respondents who were selected using the stratified proportionate and snowball sampling techniques. Data collected were analysed using descriptive and inferential statistics. Results showed that $80 \%$ of the NCE graduates work in private and public establishments and there is no significant link between employment categories of NCE graduates and their school programme type. The College has favourable learning space and both male and female respondents were satisfied with the relevance of NCE curriculum to their job assignment. There was no significant difference in their rating of curriculum relevance. Based on the findings, it is recommended that NCE Minimum Standard should be reviewed to address the training gaps observed in the NCE curriculum to enhance employability quality of its graduates. The College should utilize the opportunity of its favourable learning space to improve upon its ICT, laboratories, accommodation, clinics, students center and cafeteria
\end{abstract}

KEYWORDS: tracer study, Nigeria Certificate in Education (NCE), minimum standards, school program type

\section{INTRODUCTION}

Federal College of Education (Technical) Bichi, was established in March, 1986 alongside seven others across the country in response to global dynamics and challenges posed by science and technology. The institutions were to address the National need in technical and vocational education for the then newly introduced 6-3-3-4 educational system. The graduate teachers of the Colleges were to teach vocational and technical subjects enshrined in the former 6-3-3-4 curriculum of junior secondary schools in the country. The College has existed for over 30 years with over 27 programmes and 30 departments, yet no adequate 
information that will serve as sound basis for evaluating the attainment of college objectives. Hence, a tracer study to evaluate the products of the institution is necessary. A tracer study will avail the College with the data on the relevance and effect of technology teacher training to the society: the data of those employed, and types of employment visà-vis the training received, gaps between expectations and realities and key areas that will require revisions, reviews and improvements of the National Commission for Colleges of Education (NCCE) Minimum Standards.The National Commission for Colleges of Education (NCCE) established in 1989 came with the mandate of controlling all trainings at the NCE level. Consequently, the Commission has the task to revise, review and make policies for improvements of the NCCE Minimum Standards which is the training document used by Teacher Training Institutions in the country. Despite the reviews in 1990, 1996, 2002, 2008 and 2012, literatures established gaps in the efficiency and effectiveness of most Nigeria Certificate in Education (NCE) graduates in the Country, to meet the philosophy and objectives of the NCE (Technical) program as contained in the revised editions of the Minimum Standards.

Schomburg (2016) revealed that in many countries, conducting tracer studies is a formal requirement for the accreditation of study programmes and educational institutions are also increasingly interested in feedback from their former students to improve their study programmes, and to show new applicants how their graduates have managed the transition to employment

In Nigeria, Tracer Study is a necessary requirement and a duty of every College of Education Academic and Quality Assurance Unit. Specifically, the framework for monitoring the implementation of the new National Teacher Education (2017) has four key aspects. Two of these key aspects are National Teacher Education Policy (NTEP) log frame and Baseline measurement which depend on available data from tracer studies and other sources.

Accreditation Toolkit for the Colleges of Education (2012) also emphasised the need for tracer study reports with a view to strengthening evidence based research informing decisions on teaching effectiveness and efficiency. Worth mentioning are frequent demands for reports of tracer studies by intervention agencies such as Teachers Development Program (TDP), Teachers Upgrade Program (TUP), Universal Primary Education Boards, and Need Assessment Committees.

This outstanding technical teacher production outlet in the country requires a tracer study of her graduates so as to meaningfully respond to both the local and global effects of science and technology. Consequently, some questions need answers, for example what are the training gaps for employability and how relevant the curriculum is to the job performed by graduates? 


\section{RELATED LITERATURE}

Tracer study is a retrospective analysis of graduates through a standardised survey, which takes place sometime after graduation (Background Note, 2017). According to the ILO Thesaurus (2005) as cited in Adelaida (2014) tracer study is an impact assessment tool where the impact on target groups is traced back to specific elements of a project or programme so that effective and ineffective project components may be identified. Tracer study is sometimes referred to as follow up or transition study, graduate or alumni survey. It could also be referred to as graduate or career tracking since its target group is former students.

Issues addressed in tracer studies include biographical data on 'Where are our NCE graduates now' which may supply information on income, job title, nature of employment, and years of employment. He also believes that surveys should also include information "about the kind of work task, the relationship between study and work, and professional values and job satisfaction. The information gained from survey items can be used by the graduate's alma mater and indeed other education stakeholders for curriculum development and reform. Graduate surveys are popular for analysis of the relationship between higher education and work, provision of structural data on employment and career, the character of work and related competencies, professional success (career, status, income) and information on relevance of knowledge and skills of NCE graduates (Schomburg, 2003, 2004)

Rojas and Rojas (2016) traced the employment profile of Cebu Technological University, College of Education (CTU MC CoE) NCE graduates from 2005-2009. Mix methods of descriptive survey method and thematic analysis were used to trace their status of employment, with the use of questionnaire and personal interviews. They ascertained the profile of NCE graduates; determined relationship between their present occupation and the course they studied; and identified the cooperating industries/institution that employed NCE graduates. The CTU MC CoE NCE graduates were to be employable in the government schools. High school teachers predominate on the track than the elementary teachers with a negligible difference. The CTU mandate, as cascaded in its vision-mission, is to prepare NCE graduates for the field of work, with personality which matters more than other predetermined factors. Academic preparation and career performance exhibited are significant in successful teaching employment in the public school.

Considering the challenges of NCE teacher's employability today, it is not surprising therefore that employability and 'demand' of a certain profession is a huge factor in the choice of certificate. Consequently, one of the main goals of a higher teacher education institution is also based on the premise that NCE graduates may continually adapt the needs of a highly evolving and competitive 'market', as they serve as 'factory', a breeding ground for professionals and employees of industries in the future. To prove this context, Rojas and Rojas (2016) posited that many young professionals shift many times their jobs because of mismatch and low salaries of the first profession. 
In her tracer study of the NCE graduates of the Faculties of Agricultures and Arts, University of Nigeria, Nsukka, Anyanwu (2000) examined retrospective contribution of their education to their current work A sample of 579 NCE graduates from the population of the NCE graduates from the population of the NCE graduates of 1976-93 from the various study programmes in the two faculties were studied. Findings of the study indicated that more NCE graduates got their first job by application to vacant positions and less so through personal contacts/connections. In a descending order of importance, knowledge of English, Science and technical knowledge of the field course work and practicals were major study elements used on the current job. Field of study, area of specialization, reputation of the university, personality and grades (class of pass) were similarly major contributors to being employed. Overall, nearly three-fourths of the NCE graduates agreed that the knowledge and skills acquired during their studies were used to, at least, a great extent in their current jobs.

Fadeyi, Sofoluwe, and Gbadeyan (2015) observed that there is an impact of teachers' salary to their job performance, vis-à-vis to students' academic performance, which means higher salary of the teachers can boost their morale to perform better in teaching. In contrast Graduate Tracer Study of the University of Pangasinan reveals that new NCE graduates are challenged by the lack of job opportunities, which reasonably takes them a longer time to wait because of lack of experience (Rocaberte, 2016).

Stake holders such as teachers' commissions or basic education boards need highly skilled and competent teachers. This implies that colleges must shift their instructional competence to train teachers who are outcome-based, so that they can survive in the world of work relative on the respective careers they have chosen. However, Aquino and Punongbayan (2015) recently concluded in a tracer study of the University of Batangas among their Education NCE graduates that majority who participated in the study are NCE graduates of the Bachelor of Secondary Education (BSED) and believe that teaching is the most rewarding and challenging profession.

The AAU research project on Higher Education and Work in Africa "Higher Education and the Demands of Manpower Development in the Nigerian Manufacturing Sector: an Empirical Study of Enugu and Anambra States." was conducted in Nigeria. The findings for this project were similar to those for Malawi in terms of students' satisfaction about the utilisation of knowledge and dissatisfaction about resources. The research was used to make recommendations such as the need for:

- improved funding of higher education institutions in order to enhance their overall capacity for the provision of vital equipment, study facilities and off study infrastructure, thereby strengthening their study provisions and conditions profile and

- curriculum planning and development in higher education to be more broad based and trans-disciplinary than hitherto (Ugwuonah \& Omeje, 1998)

In Nigeria, a tracer study was done for the Nigerian Teachers' Institute (NTI) which launched its Nigeria Certificate in Education by ODL in 1990 in response to urgent need 
to train more teachers. The findings of the study were that the performance of ODL NCE graduates was as effective in the classroom as that of their peers who had studied in the traditional way. Their classroom teaching, lesson preparation, motivation of students, record keeping and communication in English were good. The students themselves rated the instructional materials provided quite highly. However the study revealed some dissatisfaction about the use of audiovisual materials. It was also thought that teachers needed to be better trained in the techniques of ODL. The Institute itself had improved its management and monitoring systems and efforts had been made to address these inadequacies. (Umar,2006).

\section{Research Questions}

The following questions guided the study:

1. What are the categories of employers of NCE graduates based on their programme type?

2. How do NCE graduates get first job?

3. What factors are involved in acquiring the first job?

4. How do NCE graduates search for new job?

5. How do NCE graduates rate study provisions?

6. What are the training gaps required for employability of NCE graduates?

7. What is the level of relevance of curriculum of the field of study to the job?

\section{Hypotheses.}

The following hypotheses were postulated:

1. There is no significant association between school program type and categories of employers of NCE graduates.

2. There is no significant difference between male and female NCE graduates' rating of the relevance of the curriculum of field of study to area of work

\section{METHODOLOGY}

\section{Design.}

The study is a descriptive survey. It applied an approach for tracer studies which should enable the institution of higher education to get information to indicate possible deficits in a given educational programme and to serve as a basis for future planning activities. It adopted the three main steps in the tracer study survey posited by Schomburg (2003). The research involved concept and instrument development, data collections, data analysis and report writing. It involved seeking opinion of NCE graduates of the college using questionnaires and interview as applicable in the design by snowballing where necessary in order to reach out to the countable population that may not be easily accessible.

\section{Population and Sample.}

The study population is made up of all students of the college who graduated between 2003 and 2015. The convocation list and schools gazette of graduating students revealed that 3,641 graduated within the years of study. At 5\% level of significance, a minimum sample 
of 375 is appropriate for a population of 5,000 NCE graduates (Mitchell and Jolley, 2004). Proportionate stratified technique was used to arrive at a sample of 590 students. Snowballing sampling technique was used to locate NCE graduates where they are not easily accessible. To ease data collection procedure, samples were also drawn using Internet and Alumni contact modes.

\section{Instrumentation.}

The instrument used was adapted from the Standard Instrument for Graduate Tracer Study 2011 of the University XY 2011. It was developed by participants of an International workshop on tracer studies in higher education at the University Kassel (October 2010). The participants were from Costa Rica, Ethiopia, Germany, Guatemala, Indonesia, Kenya, Philippines and Vietnam. It is tagged UNITRACE meaning University Graduate Tracer study Course. A few items were restructured to fit the survey of the environment and as demanded by the instrument for adaptation. The instrument was titled NCE Graduates' Tracer Study Core Questionnaire and put on the internet on the link https://docs. google.com/forms/ d/e/1FAIpQLSf7YEVMLSSfYUIv9 DmXoxyBdINI37 OeiSC9NLIYr5CKBsFJQ/viewform?usp=sf_link

\section{Data Collection Procedure and Analysis.}

Data was collected using research assistants in stages. First stage after the production of bulk questionnaires was to identify the location of respondents across the nation being a Federal College output through internet, GSM, or Alumni contact. Second stage involved was a snowballing search within the catchment area of the college. The third was to activate the internet link https://docs.google.com/forms/d/e/1FAIp QLSf7YEVMLSSfYUIv9DmXoxyBdINI37OeiSC9NLI-

Yr5CKBsFJQ/viewform?usp=sf_link. Questionnaire was accessed online and completed by some respondents while some questionnaires were administered on every successful contact made. The third stage was to download questionnaires completed online, assemble those completed on hard copies and collate the results using the appropriate codes. The questionnaires were analyzed using descriptive and inferential statistics with the aid of IBM SPSS statistical computer package, version 25.0. Analysis was based on the questions raised and null hypotheses postulated. 
Print ISSN: ISSN 2054-6351: Online ISSN: ISSN 2054-636X

FINDINGS AND DISCUSSION

Table 1. School Program Type and Year of Graduation of Respondents.

\begin{tabular}{|l|l|l|l|l|l|l|l|l|l|l|l|l|l|}
\hline \multirow{2}{*}{$\begin{array}{l}\text { School } \\
\text { program type }\end{array}$} & \multicolumn{9}{|l|}{ Year of graduation } & Total \\
\cline { 2 - 14 } & 2004 & 2005 & 2006 & 2007 & 2008 & 2009 & 2010 & 2011 & 2012 & 2013 & 2014 & 2015 & \\
\hline Business & 8 & 12 & 21 & 10 & 7 & 10 & 10 & 11 & 12 & 11 & 21 & 13 & 146 \\
PES & 0 & 0 & 7 & 4 & 3 & 5 & 4 & 4 & 3 & 4 & 10 & 6 & 50 \\
Sciences & 8 & 9 & 16 & 10 & 8 & 10 & 9 & 8 & 10 & 8 & 15 & 10 & 121 \\
Technical & 7 & 10 & 18 & 8 & 5 & 10 & 9 & 9 & 9 & 9 & 13 & 12 & 119 \\
Vocational & 9 & 14 & 21 & 10 & 10 & 10 & 11 & 12 & 11 & 12 & 20 & 14 & 154 \\
Total & 32 & 45 & 83 & 42 & 33 & 45 & 43 & 44 & 45 & 44 & 79 & 55 & 590 \\
\hline
\end{tabular}

Table 1: shows the distribution of respondents involved in the study. A total of 590 NCE graduates constitute the sample, 146(24.7\%) from Business Education School Program, 50(8.5\%) Primary Education Studies, 121(20.5\%) Science, 119 (20.2\%) Technical education and 154(26.1\%) Vocational Education.

Table2: School Program Type and Current Employers of NCE Graduates.

\begin{tabular}{l|l|l|l|l|l|l}
\hline \multirow{2}{*}{ School } & \multicolumn{3}{c|}{ Currently employers } & Total \\
\cline { 2 - 5 } & Public & $\begin{array}{l}\text { Ngo non } \\
\text { Profit }\end{array}$ & private & Self employed & others & \\
\hline Business Education & 58 & 8 & 60 & 17 & 3 & 146 \\
Primary Education Studies & 16 & 2 & 25 & 6 & 1 & 50 \\
Sciences Education & 46 & 6 & 52 & 15 & 2 & 121 \\
Technical Education & 48 & 7 & 45 & 17 & 2 & 119 \\
Vocational Education & 58 & 9 & 64 & 20 & 3 & 154 \\
Total & 226 & 32 & 246 & 75 & 11 & 590 \\
\hline
\end{tabular}

Table 2 is a cross tabulation showing the number of graduates' current employers according to their school programs. Graduates who are employed by private employers are $246(41.69 \%)$ while those employed by the public service are $226(38.31 \%)$. This shows that $80 \%$ of the NCE graduates were employed by the public and private sectors, while $20 \%$ were employed by NGO non profit, self employed and other sectors.

Table 3: Summary of Chi-Square Test of School Program Type and Current Employer.

\begin{tabular}{lcccc}
\hline Factors & $\mathrm{N}$ & $\mathrm{X}^{2}$ & $\mathrm{df}$ & Sig. \\
\hline $\begin{array}{l}\text { School Program Type and } \\
\text { Current Employers }\end{array}$ & 590 & 2.884 & 16 & 1.00 \\
\hline
\end{tabular}

Table 3 reveals $X^{2}(4,590)=2.884, P=1.00$. This implies that $P$ is not significant at .05 level of alpha. The null hypothesis which states that there is no association between school 
program type and current employer's status is accepted. Hence, this implies that the courses they offered have no link with the type of employer after graduation.

Table 4: How NCE Graduates Get First Job.

\begin{tabular}{lccc}
\hline Mode of Contact & Frequency & Percent & Rank \\
\hline Direct Companies contact & 139 & 23.6 & 1 \\
Relations & 119 & 20.2 & 2 \\
Employers contact & 110 & 18.6 & 3 \\
Advert & 95 & 16.1 & 4 \\
Others & 54 & 9.2 & 5 \\
Internet & 42 & 7.1 & 6 \\
Own business & 21 & 3.6 & 7 \\
Alumni & 10 & 1.7 & 8 \\
Total & 590 & 100.0 & \\
\hline
\end{tabular}

Table 4 represents how NCE graduates got their first job and the ranking of the modes. Direct contact of companies or establishments without checking for vacancies accounts for the $139(23.6 \%)$ respondents. NCE graduates' family relation and contact by the employer accounts for $119(20.2 \%)$ and $110(18.6 \%)$ respondents modes of contact respectively. The least mode is contact of the Alumni office. Alumni office contact has shown to be ineffective mode of contact in the study.

\section{Table 5: Factors of Getting the First Job.}

\begin{tabular}{lcc}
\hline Areas of focus by employers & Frequency & Rank \\
\hline Study program & 257 & 1 \\
Work experience & 246 & 2 \\
English proficiency & 239 & 3 \\
GPA & 236 & 4 \\
Computer skills & 205 & 5 \\
Personality and interpersonal skill & 170 & 6 \\
School reputation & 96 & 7 \\
Specification & 85 & 8 \\
Organizational experience & 74 & 9 \\
Other language proficiency & 55 & 10 \\
Third party recommendation & 53 & 11 \\
Overseas experience & 43 & 12 \\
Others Areas & 10 & 13 \\
\hline
\end{tabular}

*Respondents were allowed to select more than one factor.

In table 5, factors or aspects important for the employers in recruiting someone for the first employment were identified by respondents and each respondent was allowed to identify more than one where necessary. The study program was identified and ranked more favourably by 257 respondents, while in order of ranks, after program of study are work experience, proficiency in English, GPA, computer skill, personality and interpersonal 
skills, school reputation, specification, organizational experience, other language proficiency, overseas experience and other factors.

Table 6: How NCE Graduates Search for new Job.

\begin{tabular}{lcc}
\hline Mode of Contact & Frequency & Rank \\
\hline Contacting employers without checking for vacancies & 287 & 1 \\
Advertisement in newspapers/fliers/magazines & 118 & 2 \\
Company/school/ place of work contact & 98 & 3 \\
Internet check/ online & 97 & 4 \\
Relations( parents, friends, relatives etc) & 75 & 5 \\
State working agency contact & 54 & 6 \\
Working for Same employer & 44 & 7.5 \\
Established Own business & 44 & 7.5 \\
Others & 21 & 9 \\
Information from career development center (CDC) & 20 & 10 \\
\hline
\end{tabular}

*Respondents were allowed to select more than one mode of contact

Table 6 represents how NCE graduates search for their first job and the ranking of the modes. Contacting employers without checking for vacancies is ranked as the first main mode of searching for first job. Others in order of ranks are advertisement in newspapers, fliers and magazines, company contact, Internet check, relations, state contact, same employer, other contacts and cdc information. Modes that were not used by NCE graduates are Commercial agency contact, Alumni contacts, e-networking and internship work placement during study time. Alumni office contact has shown to be ineffective mode of contact in the study.

\section{Table 7: Training Gaps Required for Employability of NCE Graduates.}

\begin{tabular}{lll}
\hline $\begin{array}{l}\text { Area of Additional } \\
\text { Course(s) Undertaken }\end{array}$ & Frequency & Rank \\
\hline Computer operation & 259 & 1 \\
Entrepreneurial & 215 & 2 \\
None & 74 & 3 \\
Other certificates & 54 & 4 \\
Computer application & 32 & 5.5 \\
English language skills & 32 & 5.5 \\
Other foreign language & 11 & 7.5 \\
Leadership & 11 & 7.5 \\
\hline
\end{tabular}

* Respondents were allowed to select more than one course

Table 7 presents data on the courses graduates take to make up for the gaps in education acquired under the NCE curriculum. Graduates were not limited in the number of courses taken. From the scientific style of ranking, $259 \mathrm{NCE}$ graduates had to fill the gaps with computer operation courses after graduation while 215 respondents ran entrepreneurial 
courses. The least ranked courses that were necessary are other foreign languages and leadership based courses which were undertaken by 11 respondents in each case.

Table 8 : How NCE Graduates Rate Study Provisions.

\begin{tabular}{lccc}
\hline Study Provision & N & Mean rating & Rank \\
\hline Learning space & 590 & 4.72 & 1 \\
Library & 590 & 4.04 & 2 \\
Variety of subjects offered & 590 & 3.87 & 3 \\
Accommodation & 590 & 3.33 & 4 \\
ICT & 590 & 3.23 & 5 \\
Laboratory & 590 & 3.20 & 6 \\
Medical/ clinic facilities & 590 & 3.02 & 7 \\
Students' centre & 590 & 2.79 & 8 \\
Catering (Cafeteria) & 590 & 2.74 & 9 \\
\hline
\end{tabular}

Table 8 represents how NCE graduates rate study provisions and the ranking of the provisions. The provision that attracted the highest rating on a 5point scale is the learning space with mean score of 4.72. Other provisions in order of rating are Library (4.04), Variety of subjects offered (3.87), Accommodation (3.33), Information communication Technology (3.23), Laboratory (3.20), Medical facilities (3.20) and Students' centre (2.79). The least rated provision is Catering or Cafeteria. This suggest that there is space for development and hence opportunity for improvement in the provision of facilities in all areas.

Table 9: Summary of $t$ test on Relevance of NCE Curriculum to the Job.

\begin{tabular}{lcclllll}
\hline Gender & $\mathrm{N}$ & Mean & Std Deviation & Std Error & $\mathrm{t}$ & $\mathrm{df}$ & Significance \\
\hline Male & 420 & 4.0738 & .94820 & .04627 & .245 & 588 & .81 \\
Female & 170 & 4.0529 & .90535 & .06944 & & & \\
\hline
\end{tabular}

From table 9, average rating of relevance of the NCE curriculum to graduates' job assignment on a five point scale is 4.07 for male and 4.05 for female. Further computation implies that NCE graduates' mean general (male and female) rating of the curriculum in terms of relevance to the job assignment is 4.0678 (81.36\%). Also, an independent sample $\mathrm{t}$ test was conducted to compare male and female rating of the relevance of NCE curriculum to their job assignment. From the result on table 8, there was no significant difference in males rating $(\mathrm{m}=4.07, \mathrm{SD}=0.95)$ and females rating $(\mathrm{m}=4.05, \mathrm{SD}=0.9), \mathrm{t}(588)=.254$, $\mathrm{p}=0.81$. The $81.36 \%$ rating of curriculum relevance by the graduates is irrespective of gender. 


\section{DISCUSSION}

The private and public service sector employed $80 \%$ of the NCE graduates and all program types have similar employability prospects for the students. There is no significant link between the programme types and current employer's categories.

The result on gaps required for employability based on the respondents' experiences strengthens the findings on employability rate. Proficiency in computer operation and entrepreneurial skills were found as training gaps in NCE products despite the inclusion of Computer studies and entrepreneurship education courses at general studies level and departmental levels in the NCE Minimum Standard (2012). From the findings, the impact of these courses are yet to be felt either because of the span of years covered by the study or the contents of the courses are inadequate or the delivery method was not effective.

NCE graduates search for new jobs by contacting employers without checking for vacancies, by internet advertisement and company making their contacts. They used less of e-networking and alumni office contacts. However in terms of how they get the first job, it was through direct contacts of establishments or companies, family relations, employer's contact and advertisement. The least mode was alumni. This agrees partly with Anyanwu's (2000) report that graduates of Agriculture got their first job by applying to vacant positions and less through personal contacts or connections. Despite the difference in the least mode, perhaps due to the discipline and the span of years covered, of the two studies, Alumni mode remains the most unutilized.

Findings on factors relevant in securing the first job identified school, program type, work experience, GPA, English proficiency and computer skills as important in order of rating, while overseas experience and third party recommendation are least important. This is not at variance with Fadeyi, Sofoluwe and Gbadeyan's (2015) assertion on lack of experience and Anyanwu's (2000) finding that field of study, area of specialization, reputation of the university, personality and grades (class of pass) were major contributions to employment.

The AAU recommended the need to improve funding of higher education institutions for strengthening study provisions as reported by Ugwuonah and Omeje (1998). This recommendation is a lead towards improving College study provision having been rated favourably in learning space. The Library, ICT, laboratories, accommodation, clinics, students' center and cafeteria can be improved..

Male and female respondents rated the relevance of curriculum to their job assignment similarly with an average of 4.07 out of 5.0 maximum rating. That is, they are $81.36 \%$ satisfied with the relevance of the curriculum. The inferential test affirms that there was no significant difference in the rating by gender. Despite the high rating of the curricular relevance, more than half of the respondents raised the need for more practicals, improved teaching and learning resources, qualified teaching staff and modification of curriculum in specific areas such as computer and business education programmes of science and business based school program type. Provision of amenities was also emphasized as a vital 
area of improvement. It is relevant to reflect on areas of improvement based on the findings of Zembere and Chinyama (1996) where less than 50\% of respondents gave good rating for resources and facility and recommendations of AU on curricular planning and development in Ugwu Onah \& Omeje (1998). They emphasized multiple and practical skills acquisition and Curriculum review at good intervals to keep it abreast of technological and socio-cultural changes. Generally these findings present data for NCE curriculum developers as required in its Accreditation toolkit (2012), Teachers Development Programme (TDP), Teacher Upgrade Programme (TUP), Needs Assessment Committees and Universal Primary Education Boards in Nigeria.

\section{CONCLUSION}

From the analysis and discussion of results, a majority of NCE graduates work in private and public establishments and there is no significant association between school program type and current employer's status. Proficiency in computer operations and entrepreneurial skills are required for raising the employability status of NCE graduates. Alumni (association) has not been a promising source of employment search for graduates but Contact of employers, Internet, Adverts, have been the main mode of search while School programme type, Work experience, GPA, English Language Proficiency and Computer studies have helped them in securing their first job. Both male and female respondents were satisfied with the relevance of NCE curriculum to their job assignments, however, since there is a favourable learning space, the college could improve the quality of provision for optimal learning.

\section{Recommendations.}

1.Quality of teachers should be ensured especially through Continuous Professional Development Courses (CDPC), Teachers Development Program (TDP) Post graduate studies, quality workshops and trainings, or any programme equivalent to those recommended by TRCN, NTEP and NCCE. This will further fill identified training gaps. 2.NCCE needs to review its minimum standards to address the training gaps observed in the NCE curriculum to enhance employability quality of its graduates.

3. Funds should be sought by the College and should be utilized for the opportunity of its favourable learning space to improve upon its ICT, laboratories, accommodation, clinics, students center and cafeteria.

4..Alumni of each college should be further encouraged in line with the world practice and they should play their roles including documentation of their meetings and membership.

5.Every College should establish a unit that will enhance Graduate follow up and data source in liaison with Alumni. This will help to reduce challenges experienced in sampling and further tracer study procedure.

\section{References}

Adelaida, C. G. (2014). Tracer Study of PNU Graduates. American International Journal of Contemporary Research Vol. 4, 3. Retrieved from http://www.aijcrnet.com/journals/Vol_4_No_3_March_2014/１0.pdf 
Anderson, H.K., Okrah, A.K, \& Titty, C.A. (2020). Curriculum evaluation: A comparative study of a 4 year B.Ed regular and a 2 year diploma sandwich students' results in music, movement and drama. British Journal of Education.8,5. 1-14. Retrieved from https://www.eajournals.org/wp-content /uploads /CurriculumEvaluation.pdf

Anyanwu, A.G. (2000). Graduates' transition from study to employment: a study of the arts and agriculture graduates of university of nigeria in the world of work. Report Submitted to AAU. Retrieved from http://rc.aau.org/files/anyanwu.pdf

Aquino, AB and Punongbayan, EJ (2015). Teacher education graduate tracer study from 2010 to 2014 in one state university in Batangas, Philippines. Asia Pacific Journal of Multi-disciplinary Research, 3, 5. Retrieved from https://www.apjmr.com/wp-content/uploads/201 6/01/APJMR-2015-3.5. 2.06.pdf

Association of African Universities (AAU) (1995). Summary report of a colloquim jointly organized by aau and donors to african education/working group on higher education, National University of Lesotho, Jan 16-20199

ETF (2017). Skills anticipation Background Note. Tracer Studies. Evaluating the impact of training programmes from https://www.etf.europa.eu/sites/default/files/m/CEDE612F00BFF6

B3C12581A600278816_Tracer\%20studies.pdf

Fadeyi, V.T., Sofoluwe, A.O. \& Gbadeyan, R.A. (2015). Influence of teachers' welfare scheme on job performance in selected kwara state secondary schools. Asia Pacific Journal of Education, Arts and Sciences. 2(4). Retrieved from https://www. academia.edu/31189610/ Influence_of _Teachers _Welfare_Scheme_on_Job_Performance_in_Selected_Kwara_State_Secondary Schools.

Federal Ministry of Education. (2014). National teacher education policy. Abuja,FME.

Federal Ministry of Education. (2017). A framework for monitoring the implementation of national teacher education policy. Abuja, FME.

INCHER-Kassel. (2011). Graduate Tracer Study 2011 of the University XY Core Questionnaire 2011 Retrieved from https://ingradnet.org/quest/q_unitrace_2010_master_en.pdf.

Millington, C.(nd). The use of tracer studies for enhancing relevance and marketability in online and distance education. Retreived from https://wikieducator. org/images/e/e1/PID_424.pdf.

Mitchell, L.M. \& Jolley, M.J. (2004). Research design explained. Canada: Thomson Wadswort.

National Commission for Colleges of Education (2012). Curriculum implementation frameworkfor nigeria certificate in education. Abuja, NCCE

Rocaberte, T.G. (2016). The university of pangasinan graduate tracer study. Retrieved from https:/ /www. scribd. com/ doc/28709371/The-University-of-Pangasinan Graduate- Tracer-Study 
Rojas, T. T. \& Rojas, C.R.(2016). College of education graduate tracer study (gts): boon or bane?. $\quad$ European Scientific Journal. 12 (16), DOI 6378.10.19044/esj.2016.v12n16p63.

Schomburg, H. (2003) Handbook of tracer studies. Retrieved from http://www.uni. kessel.de/wz/ proj/ edwerk/mat/ handbook_vz.doc

Schomburg, H. (2016). Carrying out tracer studies: Guide to anticipating and matching skills and jobs. Vol $6 . \quad$ Retrieved from https://www.etf.europa.eu/sites/default/files/m/CEDE612F00BFF 6B3C12581A 600278816_Tracer\%20studies.pdf

Ugwounah G.E. \& Omeje K.C. (1998) Final Report of Tracer Study Research Project on Higher Education andWork. Institute for Development Studies, University of Nigeria, Enugu Campus. Retrieved from http://www.aau.org/studyprogram/ notpub/ugowomeje.pdf

Umar, A. (2006). Quality Assurance Procedures in Teacher Education: The case of the National Teachers Institute, Kaduna, Nigeria. In Perspectives on Distance Education: Toward a Culture of Quality eds. Badir K. Koul \& Asha Kanwar. Commonwealth of Learning http://www.col.org/colweb/webdav/site/myj ahiasite/shared/docs/PS-QA_chapter5.

Zembere S.N. \& Chinyama N.P.M. (1996) "The University of Malawi Graduate Tracer Study". University of Malawi. Blantyre. http://www.aau.org/studyprogram/notpub/ ZEMBERE. pdf

\section{Acknowledgement.}

The study is a TETfund (IBR) grant to the author and co-researcher, hence a profound gratitude and appreciation is extended to TETfund Management. 